\title{
Analisis Framing Kontra Narasi Terorisme dan Radikalisme di Media Sosial (Studi Kasus pada Akun @dutadamaijabar)
}

\author{
Ridwan Rustandi* \& Khoiruddin Muchtar \\ UIN Sunan Gunung Djati Bandung \\ Laksanamekar Desa Margamukti Kecamatan Pangalengan, Kabupaten Bandung, Jawa Barat 40378 \\ *e-mail : ridwanrustandi@uinsgd.ac.id
}

\begin{abstract}
The spread of terrorism and radicalism is carried out in new ways through digital technology media such as the internet. One of the most used virtual social relations spaces in the world is social media. Based on data, until 2020, active social media users in the world reach 3.5 billion people, while in Indonesia, it reaches 132 million people. This research is focused on exploring the counter-narrative of terrorism and radicalism carried out by the West Java Regional Peaceful World Maya Ambassador through the @dutadamaijabar Instagram account. The research was conducted with a qualitative approach through framing analysis. The Gamson and Modigliani models were selected to describe the media packaging kits produced by @dutadamaijabar. The results of the study concluded that the counter-narrative orientation of terrorism and radicalism @dutadamaijabar includes two forms, namely online and offline. The content production process involves three main areas, namely the blogger team, DKV, and IT. The core frame is built on three main issues, namely the nationalism-oriented narrative, a narrative of peace based on religious moderation, and a humanitarian narrative by reinforcing tolerance. Meanwhile, condensing symbols are formed by linking text, video, audio, images, and other forms by the counter-narrative core framing. Framing of media content is carried out by following the framework of framing devices and reasoning devices.
\end{abstract}

Keywords: counter narrative, terrorism, radicalism, framing analysis, social media.

\begin{abstract}
ABSTRAK
Penyebaran paham terorisme dan radikalisme dilakukan dengan cara baru melalui medium teknologi digital seperti internet. Salah satu ruang relasi sosial virtual yang paling banyak digunakan oleh masyarakat di dunia adalah media sosial. Berdasarkan data, sampai tahun 2020 pengguna aktif media sosial di dunia mencapai angka 3,5 milyar orang, sementara di Indonesia mencapai 132 juta orang. Penelitian ini difokuskan untuk menggali kontra narasi terorisme dan radikalisme yang dilakukan oleh Duta Damai Dunia Maya Regional Jawa Barat melalui akun Instagram @dutadamaijabar. Penelitian dilakukan dengan pendekatan kualitatif melalui analisis framing. Model Gamson dan Modigliani dipilih untuk menguraikan perangkat-perangkat pengemasan media yang diproduksi oleh @ dutadamaijabar. Hasil penelitian menyimpulkan bahwa orientasi kontra narasi terorisme dan radikalisme @dutadamaijabar meliputi dua bentuk yakni secara online dan ofline. Proses produksi konten melibatkan tiga bidang utama yakni tim bloger, DKV dan IT. Core frame dibangun dalam tiga isu utama, yakni narasi kebangsaan yang berorientasi nasionalisme; narasi perdamaian yang berlandaskan moderasi beragama; dan narasi kemanusiaan dengan memperkuat sikap toleran. Sementara itu, condensing symbol dibentuk dengan mempertautkan teks, video, audio, image, dan bentuk lainnya yang sesuai dengan core framing kontra narasi. Pembingkaian konten media ini dilakukan dengan mengikuti kerangka framing devices dan reasoning devices.
\end{abstract}

Kata kunci: kontra narasi, terorisme, radikalisme, analisis framing, media sosial. 


\section{Latar Belakang}

Marshal McLuhan mengistilahkan perkembangan teknologi digital sebagai sebuah prasyarat perwujudan global village. Yakni, ruang komunikasi yang bersifat interaksional tanpa ada sekat geografis. Setiap orang dengan mudah terhubung melalui jagatmaya dalam bentuk komunikasi virtual (McLuhan, 1964).

Teknologi digital memiliki andil besar dalam proses transformasi masyarakat dunia. Perubahan ini dimulai dari adanya diteritorialisasi budaya dalam wujud artifisial, sampai dengan percepatan kehidupan digital. Faktanya, penetrasi teknologi digital mempengaruhi berbagai leading sector kehidupan masyarakat dunia. Teknologi digital menjadi perangkat media yang akrab dengan berbagai kalangan masyarakat dunia. Berdasarkan rilis data https://wearesocial.com tercatat bahwa sampai Januari 2020 sebanyak 4,5 milyar penduduk dunia menjadi pengguna internet aktif (internet active users). Dari jumlah tersebut, 3,5 milyar manusia merupakan pengguna aktif media sosial (social media active users) (weareSocial, 2020).

Di Indonesia sendiri, weareSocial merilis bahwa sampai tahun 2018 terdapat 132 Juta penduduk yang menjadi internet active users. Dari total tersebut, 130 juta penduduk merupakan social media active users. Sementara itu, Asosiasi Penyelenggara Jasa Internet Indonesia (APJII) mencatat ada kenaikan signifikan berkaitan dengan pengguna aktif internet di Indonesia. Sampai tahun 2018, pengguna aktif internet di Indonesia mencapai angka 64,8 persen. Artinya, terdapat 171,17 juta penduduk Indonesia dari total 265 juta yang menjadi internet active users (APJII, 2020).

Data di atas menunjukkan bagaimana tingkat penetrasi teknologi digital (internet) dalam kehidupan masyarakat dunia. Kehadiran teknologi digital tersebut diikuti oleh penemuan-penemuan baru perangkat teknologi komunikasi dan informasi yang menawarkan berbagai kemudahan bagi kehidupan keseharian manusia. Sehingga, penetrasi teknologi digital dengan mudah menyebar dan merombak hampir sebagian besar tatanan kehidupan masyarakat, baik dalam bidang sosial, budaya, ekonomi, pendidikan, politik dan bahkan agama.

Secara sosiologis, transformasi tatanan kehidupan manusia dirasakan dengan adanya perubahan struktur interaksional. Teknologi digital seperti internet menawarkan cara interaksi dan komunikasi baru. Interaksi cara baru tersebut dilakukan secara virtual melalui ruang mayantara (cyberspace), dan model komunikasinya adalah model komunikasi virtual. Oleh karenanya, ruang dan komunikasi virtual ini melahirkan realitas virtual yang berpengaruh terhadap pola dan proses relasi sosial manusia.

Relasi sosial virtual mengandaikan adanya transformasi kehidupan yang sebagian besar dimediasi secara mendasar oleh teknologi, sehingga berbagai fungsi alam kini diambil alih oleh substitusi teknologisnya, yang disebut kehidupan artifisial (artificial life). Setidaknya, relasi sosial virtual ini berlangsung dalam tiga tingkatan, yakni pada tingkat individu yang berpengaruh terhadap identitas diri; pada tangkat antar-indivudi yang melahirkan relasi virtual seperti virtual shopping, virtual game, virtual conference, virtual sex dan virtual mosque; dan pada tingkat komunitas yang menciptakan satu model komunitas demokratik dan terbuka (Piliang, 2012: 147148).

Salah satu media komunikasi virtual yang paling banyak dan berpengaruh dalam kehidupan masyarakat adalah media sosial. Sebanyk 3,5 milyar penduduk dunia dan 132 juta penduduk Indonesia yang menjadi pengguna aktif media sosial. Media sosial menjadi ruang artifisial yang dijadikan sebagai medium mengkomunikasikan 
berbagai kebutuhan dan kepentingan masyarakat. Media sosial menjadi medium yang memungkinkan pengguna merepresentasikan dirinya dalam proses berinteraksi, berbagi, bekerjasama dan berkomunikasi dengan pengguna lain serta membentuk ikatan sosial secara virtual (Nasrullah, 2015: 2,11).

Masifnya penggunaan media sosial memungkinkan media sosial menjadi salah satu pembentuk peradaban dan cara berkebudayaan. Media sosial secara fundamental merubah cara kita berpikir, pola interaksi dan relasi sosial melalui caracara berkebudayaan baru, seperti mediasi komunikasi, texting culture, emoticon, teleconference, digital learning, Islamic lectures, sampai dengan relasi sosial virtual yang berdampak negative seperti cyber-sex, cyber-crime dan lain sebagainya (Piliang, 2012: 2; Fakhruroji, 2015: 234; Nurdiarti, 2018: 59-6o; Fakhruroji, 2018).

Dalam konteks kebangsaan, perkembangan teknologi digital tidak hanya digunakan dalam aspek-aspek kehidupan yang memunculkan dampak positif. Tetapi juga berdampak negatif sehingga berekses terhadap ikatan kebangsaan di antara warga (civil society). Salah satu isu kebangsaan yang aktual dan mendapat sorotan dari berbagai pihak adalah berkenaan dengan aksi dan narasi terorisme dan radikalisme.

Merujuk pada UU No 15 tahun 2018 tentang Tindak Pidana Terorisme, terorisme didefiniskan sebagai perbuatan yang menggunakan kekerasan atau ancaman kekerasan yang menimbulkan suasana teror atau rasa takut secara meluas, yang dapat menimbulkan korban yang bersifat massal, dan/atau menimbulkan kerusakan atau kehancuran terhadap objek vital yang strategis, lingkungan hidup, fasilitas publik, atau fasilitas internasional dengan motif ideologi, politik, atau gangguan keamanan.
Sementara itu, radikalisme diartikan sebagai suatu paham yang dibuat-buat oleh sekelompok orang yang menginginkan perubahan atau pembaharuan sosial dan politik secara drastis dengan menggunakan cara-cara kekerasan. Faham ini diidentikkan dengan paham keagamaan yang melampaui batas, dianggap mutlak, berkaitan dengan persoalan politik dan ideologi tertentu, sehingga melahirkan sikap ekstremisme dan intoleran (Turmudi, 2012; Asrori, 2015: 257; Utomo, 2016: 3i Ahdar, 2017: 22-23; Markum \& Winarno, 2020: 45).

Aksi dan narasi terorisme dan radikalisme seolah mendapat "angin segar" ketika menggunakan medium digital sebagai ruang propaganda. Propaganda terorisme dan radikalisme di dunia maya lebih dominan menyasar generasi muda. Salah satu faktor pendorong maraknya penyebaran aksi dan narasi terorisme dan radikalisme bagi kalangan generasi muda adalah dikarenakan tingkat keteraksesan generasi muda sangat tinggi terhadap internet. Hal ini diperkuat oleh hasil riset dari PPIM UIN Jakarta dan Convey Indonesia yang melibatkan 264 Guru PAI, 58 Dosen, 1522 Siswa dan 337 mahasiswa dari 34 provinsi dan 68 kota/kab (PPIM UIN Syarif Hidayatullah \& Convey Indonesia, 2018).

Selain itu, tingkat pengguna internet di Indonesia hampir 90 persen berasal dari kalangan anak muda dalam rentang usia 1530 tahun (APJII, 2018). Propaganda mayantara dilakukan sebagian besar dengan memanfaatkan ruang relasi virtual setidaknya, 130 juta penduduk Indonesia menjadi pengguna aktif media sosial (weareSocial, 2018). Platform media sosial terbesar yang banyak digunakan oleh pengguna internet di Indonesia adalah Facebook $(50,7 \%)$, Instagram (17,8\%), Youtube $(15,1 \%)$, Twitter $(1,7 \%)$ dan Linkedin (0,4\%). Sementara, sebesar $7,1 \%$ 
menyatakan tidak pernah menggunakan media sosial (APJII, 2018).

Data di atas dapat dijadikan sebagai rujukan, betapa tingginya popularitas media sosial sebagai ruang virtual yang paling banyak digunakan. Sehingga, menjadi wajar sejak tahun 2013, organisasi terorisme seperti ISIS memanfaatkan platform media sosial (terutama) Twitter sebagai medium propaganda dalam melancarkan aksi dan narasi terorisme dan radikalisme.

Nuruzzaman (2018: 71) melakukan penelitian yang dilakukan dalam kurun waktu setahun (2015-2016). Hasil penelitiannya menunjukkan, ada 106.000 aktivis pro ISIS yang menggunakan media sosial untuk propaganda. Ada 166 grup di media sosial yang digunakan untuk membangun jaringan. Dalam satu hari, setidaknya ada 90.000 pesan pro ISIS yang bertebaran dan berseliweran di media sosial. Dalam 24 jam, rata-rata ada 270 kicauan di twitter yang menggambarkan pro ISIS. Mereka memanfaatkan media sosial untuk menjaring anak-anak muda bergabung. Rata-rata mereka yang mencari identitas diri. Data ini menunjukkan bahwa dalam konteks ke-Indonesiaan, narasi terorisme dan radikalisme disebarkan secara masif melalui jejaring sosial seperti Facebook, Instagram, dan Twitter (Muthohirin, 2015; Wahab, 2020).

Masifnya propaganda aksi dan narasi teorisme dan radikalisme di media sosial yang menyasar anak muda menimbulkan gerakan perlawanan dalam bentuk kontra narasi yang dilakukan oleh beberapa elemen bangsa Indonesia. Dalam hal ini pemerintah RI melalui Kementerian Pertahanan, Kementerian Kominfo, BNPT RI dan berbagai leading sektor lainnya merumuskan program kontra narasi terorisme dan radikalisme sebagai upaya bentuk pencegahan terorisme di Indonesia.

Selain itu, gerakan kontra narasi ini dilakukan pula oleh komunitas, NGO dan elemen masyarakat sebagai upaya pelibatan dan penyebaran narasi perdamaian di dunia maya. Misalnya yang dilakukan oleh Young Interfaith Peacemaker Community (YIPC), PeaceGeneration, Sekolah Damai Indonesia, Maarif Institute, Wahid Foundation, Jaringan Gusdurian, Duta Damai Dunia Maya, dan lain sebagainya.

Propaganda kontra narasi dalam melawan terorisme dan radikalisme di media sosial ini dilakukan secara variatif. Misalnya menggunakan narasi-narasi agama, konsep pendidikan, narasi perdamaian, dialog lintas agama, counter hoax dan hatespeech kampanye hastag di medsos, penanaman nasionalisme dan sikap toleransi, kontra narasi berbasis komunitas, konten internet dalam bentuk DKV seperti meme, desain flyer dan video, pelatihan internet sehat, literasi media digital, termasuk gerakan edukasi dan sosialisasi dalam bentuk pelatihan keterampilan (Sutantohadi \& Wakhidah, 2017; Fahmi, 2018; Digdoyo, 2018; Dewi \& Triandika, 2020; Wahab, 2020).

Merujuk pada data dan fakta di atas, penelitian ini bertujuan untuk menganalisis kontra narasi terorisme dan radikalisme yang dilakukan oleh Duta Damai Dunia Maya BNPT RI. Adapun yang menjadi objek penelitian ini adalah segala hal yang berkaitan dengan produk kontra narasi terorisme dan radikalisme yang dilakukan oleh Duta Damai Jawa Barat di media sosial. Sementara subjek penelitiannya adalah akun Instagram @dutadamaijabar yang menggambarkan produk kontra narasi teorisme dan radikalisme di dunia maya. Pembatasan pada akun Instagram didasarkan pada hasil observasi dan wawancara awal bahwa produk kontra narasi pada akun Instagram dipandang merepresentasikan pada media lainnya. Duta Damai Jawa Barat merupakan salah satu relawan penggerak perdamaian yang 
terbentuk melalui Pelatihan Duta Damai Dunia Maya. Pelatihan ini dilaksanakan sebagai upaya pencegahan terorisme dan radikalisme bagi generasi muda. Secara hierarkis, Duta Damai Dunia Maya berada di bawah Deputi Bidang Pencegahan, Direktur Pencegahan, Kasubdit Kontra Propaganda, Kasie Literasi Media, dan Pusat Media Damai (PMD) Badan Nasional Penanggulan Terorisme (BNPT) RI. Duta Damai Dunia Maya berisi sekolompok anak muda yang memiliki keterampilan dalam bidang bloger, DKV dan IT untuk menjadi promotor perdamaian di dunia maya.

Sampai tahun 2020 telah terbentuk 13 regional Duta Damai Dunia Maya di seluruh Indonesia, antara lain Jakarta, Sumatera Utara, Sulawesi Selatan, Yogyakarta, Jawa Barat, Jawa Tengah, Jawa Timur, Banten, Sumatera Barat, Sulawesi Utara, NTB, Kalimantan Selatan dan Kalimantan Timur. Pembentukan Relawan Penggerak Perdamaian (Duta Damai Dunia Maya) merujuk pada Peraturan BNPT RI (Perban) Nomor 4 Tahun 2019 Tentang Duta Damai sebagai Relawan Penggerak Perdamaian dalam Pencegahan Radikal Terorisme di Dunia Maya.

Duta Damai Dunia Maya Regional Jawa Barat terbentuk sejak tahun 2016 melalui Pelatihan Duta Damai yang diselenggarakan di Bandung. Terdapat kurang lebih 6o anak muda dikategorisasikan berdasarkan kemampuan di bidang Bloger, IT dan DKV yang konsisten melakukan kontra narasi perdamaian melawan terorisme, radikalisme, hoax dan hatespeech. Duta Damai Dunia Maya aktif melakukan kontra narasi baik melalui website

(http://www.dutadamaijawabarat.id/) maupun media sosial (facebook, twitter, Instagram dan youtube).

Keberadaan Relawan Penggerak Perdamaian seperti Duta Damai Jawa Barat dipandang penting, mengingat provinsi
Jawa Barat termasuk provinsi yang memiliki jumlah penduduk sampai dengan 49, 32 juta (Badan Pusat Statistik Jawa Barat, 2020). Selain itu, provinsi Jawa Barat memiliki tingkat kepadatan penduduk yang cukup tinggi dengan latar belakang penduduk yang multikultural baik dari sisi budaya, pemahaman agama, kesukuan, dan lain sebagainya. Sehingga, provinsi Jawa Barat termasuk salah satu provinsi yang memiliki rawan dengan gerakan terorisme dan radikalisme.

Selain itu, dari sisi penetrasi pengguna internet, provinsi Jawa Barat termasuk pengguna internet terbesar di Indonesia. Dari total 95,25 juta pengguna aktif internet di Pulau Jawa, 16,7 persen adalah penduduk Jawa Barat. Itu berarti terdapat sekitar 15,33 juta pengguna aktif internet di Jawa Barat (APJII, 2020). Dengan jumlah tersebut, tidak menutup kemungkinan penyebaran propaganda aksi dan narasi terorisme dan radikalisme di Jawa Barat memanfaatkan medium digital dengan masif dan strategis.

Oleh sebab itu, penelitian ini dilakukan sebagai upaya menggali gerakan kontra narasi terorisme dan radikalisme yang dilakukan oleh Duta Damai Dunia Maya BNPT RI Regional Jawa Barat. Penelitian dilakukan dengan menganalisis akun media sosial Instagram @dutadamaijabar. Pembatasan akun Instagram sebagai subjek penelitian dilakukan dengan alasan bahwa akun Instagram @dutadamaijabar dipandang merepresentasikan produk kontra narasi terorisme dan radikalisme pada media lainnya, baik website, facebook, twitter dan Youtube. Hal ini merujuk pada hasil observasi dan wawancara awal dengan pengurus DD Jawa Barat bahwa postingan pada akun Instagram diambil dari website dengan tujuan menyederhanakan produk kontra narasi yang bisa diakses oleh pembaca secara visual dan singkat serta postingan instagram disinkronisasikan dengan facebook dan twitter. Selain itu, 
metode analisis framing digunakan dalam penelitian ini untuk menganalisis ruang pembingkaian dan konstruksi kontra narasi terorisme dan radikalisme @dutadamaijabar dalam bentuk desain visual seperti flyer, poster dan video, maupun narasi dalam bentuk teks. Kontra narasi terorisme dan radikalisme ini dilihat dari media package yang terdiri dari dua struktur utama, yakni core frame dan condensing symbol.

\section{Metode}

Penelitian ini menggunakan pendekatan kualitatif dengan analisis teks media. Analisis framing digunakan untuk menganalisis pembingkaian media mengenai suatu isu tertentu. Analisis teks media dengan metode framing dipilih karena dalam penelitian ini analisis media package dilakukan untuk memahami wacana sebagai kumpulan perspektif interpretasi saat memberikan makna suatu isu (Sobur, 2001: 161). Adapun yang menjadi objek penelitian ini adalah segala hal yang berkaitan dengan gerakan kontra narasi terorisme dan radikalisme yang dilakukan oleh Duta Damai Jawa Barat di media sosial. Sementara subjek penelitiannya adalah akun Instagram @dutadamaijabar yang menggambarkan produk kontra narasi teorisme dan radikalisme di dunia maya.

Secara sederhana, analisis framing dapat digambarkan untuk mengetahui bagaimana realitas (peristiwa, aktor, kelompok atau apa saja) dibingkai oleh media (Eriyanto, 2002: 68). Analisis ini juga dapat digunakan untuk membuka peluang implementasi konsep sosiologis, politik dan kultural dalam menganalisis fenomena komunikasi. Analisis framing digunakan untuk menggali pembingkaian media berkaitan dengan konstruksi kontra narasi terorisme dan radikalisme di media sosial. Dalam hal ini, data penelitian berupa dokumen yang dianalisis, yakni dokumen- dokumen yang ada pada akun Instagram @dutadamaijabar.

Data dikumpulkan melalui teknik observasi, wawancara, dokumentasi dan kajian pustaka. Observasi dan dokumentasi dilakukan dengan menganalisis akun @dutadamaijabar terkait dengan topik penelitian. Wawancara dilakukan kepada pengurus dan/atau pengelola Duta Damai Jawa Barat dengan tujuan mengkonfirmasi hasil analisis framing berkaitan dengan produk-produk kontra narasi terorisme dan radikalime pada akun Instagram Duta Damai Jawa Barat. Sementara kajian pustaka dilakukan dengan menggali sumber rujukan yang relevan baik dari jurnal maupun buku primer.

Analisis data dilakukan merujuk pada konep framing media berkaitan dengan kontra narasi terorisme dan radikalisme di akun @dutadamaijabar. Tahapan analisis data disesuaikan dengan perangkat framing model Gamson dan Modigliani baik pada sisi teks, narasi, wacana, gambar, grafik, citra dan foto.

Model analisis framing yang digunakan dalam penelitian ini adalah model William A. Gamson dan Modigliani. Model ini mengoperasionalisasikan dua dimensi struktural teks media, yakni core frame dan condensing symbol. Pada dimensi pertama merupakan pusat-pusat elemen ide yang membantu komunikator untuk menunjukkan substansi isu yang tengah dibicarakan. Sementara struktur kedua mengandung dua substruktur yakni, framing devices dan reasoning devices (Sobur, 2001: 176).

Secara operasional perangkat framing dalam model Gamson dan Modigliani dapat dilihat pada tabel berikut:

Tabel 1 Perangkat Framing Model Gamson dan Modigliani

\begin{tabular}{ll}
\hline Framing Devices & Reasoning Devices \\
\hline Methapors & Roots \\
$\begin{array}{l}\text { Perumpamaan atau } \\
\text { pengandaian }\end{array}$ & Analisis kausal \\
\hline
\end{tabular}




\begin{tabular}{|c|c|}
\hline Exemplars & \\
\hline $\begin{array}{l}\text { Mengemas makna } \\
\text { tertentu } \\
\text { memiliki } \\
\text { makna lebih } \\
\text { dijadikan rujukan }\end{array}$ & $\begin{array}{l}\text { Premis dasar, klaim- } \\
\text { klaim moral }\end{array}$ \\
\hline $\begin{array}{l}\text { Catchprases } \\
\text { Frase yang menarik, } \\
\text { kontras, menonjol } \\
\text { dalam suatu wacana. } \\
\text { Ini umumnya berupa } \\
\text { jargon. }\end{array}$ & \\
\hline Depiction & \\
\hline $\begin{array}{lr}\text { Penggambaran } & \text { atau } \\
\text { pelukisan } & \text { suatu isu } \\
\text { yang } & \text { bersifat } \\
\text { konotatif. } & \text { Ini } \\
\text { umumnya } & \text { berupa } \\
\text { kosakata, } & \text { leksikon } \\
\text { untuk } & \text { melabeli } \\
\text { sesuatu. } & \\
\end{array}$ & \\
\hline \begin{tabular}{lr}
\multicolumn{2}{l}{ Visual Images } \\
Gambar, grafik, citra \\
yang mendukung \\
bingkai & secara \\
keseluruhan. & Bisa \\
berupa foto, kartun \\
atau grafik untuk \\
menekankan ran \\
mendukung pesan \\
yang & ingin \\
disampaikan. & \\
\end{tabular} & \\
\hline
\end{tabular}

Sumber: Eriyanto, 2002: 165

\section{Pembahasan}

\section{a. Kondisi Objektif dan Orientasi Kontra Narasi Duta Damai Jawa Barat}

Duta Damai Dunia Maya BNPT RI Regional Jawa Barat merupakan relawan penggerak perdamaian yang dibentuk untuk melakukan kontra narasi radikalisme, terorisme, hoax dan hate speech. Duta Damai dibentuk melalui sebuah pelatihan yang diselenggarakan oleh Badan Nasional Penanggulangan Terorisme (BNPT) RI melalui Deputi Bidang Pencegahan, Subdit Kontra Propaganda, Seksi Literasi Media dan Pusat Media Damai (PMD). Pelatihan ini dilakukan melalui pembekalan dan pembidangan tiga potensi yakni, blogger, DKV dan IT. Ketiga dibentuk menjadi promotor perdamaian yang konsens melakukan gerakan di dunia maya baik melalui website dan media sosial.

Duta Damai Dunia Maya (disingkat DD) regional Jawa Barat terbentuk pada tahun 2017 di Bandung. Pelatihan DD Jawa Barat berlangsung sejak tanggal 10-13 April 2017. Secara keanggotaan, DD Jawa Barat terdiri dari 60 orang anggota yang merupakan anak muda dengan tiga pembidangan kemampuan. Keenampuluh anak muda tersebut terdiri dari berbagai latar belakang aktivitas, baik mahasiswa, pelajar, dosen, guru, pegiat media sosial, pegiat film, dan lain sebagainya. Secara teknis gerakan, 60 anggota DD Jawa Barat dibagi ke dalam 5 kelompok redaksional yang masing-masing memiliki website dan media sosial. Kelima redaksi tersebut yakni 1) Cahaya Duta Damai; 2) Bhinneka Duta Damai; 3) Hanjuang Duta Damai; 4) Saung Duta Damai; dan 5) Aku Duta Damai.

Pada prinsipnya, DD Jawa Barat melalui lima kelompok redaksional di atas melakukan proses edukasi, sosialisasi dan konstruksi narasi kontra terorisme dan radikalisme baik secara online maupun ofline. Konstruksi narasi dan aksi dalam jaringan (online) dilakukan melalui serangkaian kampanye tentang bahaya ancaman terorisme dan radikalisme bagi anak muda dan penyebaran berita hoax dan hatespeech. Gerakan daring dilakukan baik dengan menulis (blogging), desain grafis, videografi dan shortmovie. Media virtual yang paling sering digunakan adalah website DD Jawa Barat dan media sosial baik facebook, Instagram dan twitter.

Sementara itu, gerakan di luar jaringan (ofline) dilakukan dalam berbagai bentuk dan format kegiatan, seperti pelatihan JDS (Jurnalis Damai Sekolah) untuk pelajar SMA, Bincang Damai (Peacetalk) dengan berbagai komunitas, organisasi dan instansi pemerintah, Workshop Internet Sehat, Peace-campaign di ruang publik terbuka (CFD, Taman, Rumah Ibadah, Pasar, 
Terminal dll), Peace-camp, Pemberdayaan

Desa Damai, Pelatihan Mubaligh Damai, dan lain sebagainya.

Visi dan misi DD Jawa Barat adalah membentuk generasi damai Indonesia melalui promosi narasi perdamaian, kolaborasi komunitas perdamaian dan penguatan peran serta anak muda di lingkungan masyarakat dalam membentuk masyarakat damai. Visi dan misi ini diterjemahkan melalui dengan mempromosikan narasi-narasi perdamaian sebagai upaya preventif penyebaran ideologi yang berkaitan dengan terorisme dan radikalisme. Pada praktiknya, DD Jawa Barat mengelola website http://dutadamaijawabarat.id/ sebagai ruang kreativitas dalam mempromosikan nilai-nilai perdamaian, kemanusiaan dan kebangsaan.

Adapun gerakan promosi perdamaian lainnya dilakukan melalui media sosial dengan memposting berbagai narasi baik dalam bentuk meme, video, desain grafis, infografis dan lain sebagainya. Berdasarkan hasil amatan di jejaring media sosial, DD Jawa Barat aktif melakukan kontra narasi terorisme dan radikalisme dalam dalam bentuk thread di akun twitter @dutadamaijabar; produksi konten DKV di akun facebook @dutadamai.jabar.7 dan akun Instagram @dutadamaijabar; dan vloging pada kanal Youtube Duta Damai Jabar.

Berdasarkan hasil penelitian, disimpulkan bahwa: Pertama, orientasi kontra narasi yang dilakukan DD Jawa Barat dalam bentuk penanaman mentality, mindset, skillset dan society generasi muda yang kreatif dan inovatif. Proses penanaman ini diarahkan pada pembentukan kepribadian anak muda yang memiliki dimensi kebangsaan (sikap nasionalisme) yang unggul dalam menyongsong abad digital. Hal ini sebagaimana disampaikan bahwa:
"Program online dan ofline yang dirumuskan oleh DD Jawa Barat adalah upaya dalam menciptakan ekosistem perdamaian di Indonesia" (wawancara dengan HS, Pimred dan web admin DD Jabar).

Kedua, DD Jawa Barat memiliki target kontra narasi yang diarahkan untuk penyadaran dan partisipasi anak muda dalam membangun ekosistem perdamaian. Ekosistem anak muda yang damai yang dimaksud adalah ruang kreativitas dan inovasi dalam pemanfaatan teknologi digital tetapi diarahkan untuk menguatkan dimensi kebangsaan. Oleh sebab itu, sasaran dan target gerakan kontra narasi DD Jawa Barat diarahkan pada ruang-ruang kreativitas anak muda seperti sekolah, kampus, masjid dan/atau rumah ibadah lainnya dan desa.

"Kita konsisten mengajak seluruh anak muda baik di dunia nyata maupun di dunia maya untuk terlibat aktif menjaga keutuhan bangsa dengan skill yang dimilikinya" (wawancara dengan MSL, tim DKV DD Jabar, Social Media Admin).

Ketiga, kontra narasi dirumuskan secara kolaboratif dan sinergis. Kolaborasi tiga tim utama yang ada di DD Jawa Barat menjadi strategi dalam merumuskan konten-konten narasi perdamaian. Termasuk dalam pemilihan isu strategis baik mengenai kebangsaan, kemanusiaan, perdamaian, keislaman dan local wisdom atau kearifan budaya.

"DD Jawa Barat memiliki prinsip sareundeuk saigel sobobot sapihanean sabata sarimbangan (terj. Gotong royong, hidup rukun, selalu bersamasama tak pernah bertengkar karena berbeda pendapat, rukun dan saling menghargai). Peribasa sunda ini dipegang sebagai spirit kerja-kerja produktif kita dalam membuat dan menyebarkan pesan-pesan perdamaian 
untuk anak muda" (wawancara dengan

MN, Wakil Koordinator DD Jabar).

Adapun secara teknis proses kreatif kontra narasi terorisme dan radikalisme yang dilakukan oleh DD Jawa Barat dilakukan di mulai dari:

(1) riset aktual tentang apa yang sedang in di kalangan generasi muda; kemudian (2) penentuan topik narasi yang dilakukan baik oleh tim bloging, DKV dan IT, untuk selanjutnya dilakukan (3) pembuatan artikel lepas oleh tim bloger merujuk pada topik isu yang diangkat dan aktual; setelah selesai dilakukan (4) proses desain grafis oleh tim DKV dengan merujuk pada isi artikel; desain grafis dibuatkan versi (5) video grafis oleh tim DKV; setelah selesai konten diproduksi kemudian dilakukan (6) FGD penentuan publikasi konten oleh tim redaksi; setelah disepakati kemudian (7) publikasi konten di website dan media sosial oleh tim IT dan social media admin; dan (8) proses monitoring respons dari pembaca atau followers media sosial.

Dengan demikian, orientasi kontra narasi terorisme dan radikalisme yang dilakukan oleh DD Jawa Barat dilakukan untuk meningkatkan spirit dan dimensi kebangsaan (nasionalisme unggul) anak muda di era digital, membentuk ekosistem perdamaian di berbagai aktivitas anak muda dan merumuskan produksi konten digital melalui kolaborasi dan partisipasi. Ketiga orientasi ini dilekatkan dengan berbagai analisis isu strategis yang sedang aktual di kalangan anak muda baik pada aspek kebangsaan, kemanusiaan, perdamaian, keislaman dan kearifan budaya lokal.

\section{b. Core Frame: Pemilihan Isu Kontra Narasi @dutadamaijabar}

Wacana media massa seringkali menawarkan kerangka makna alternatif kepada khalayak untuk mendefinisikan diri sendiri, orang lain, lingkungan sosial, peristiwa-peristiwa, dan objek-objek di masyarakat (Achmad, 2001:29). Dalam hal ini, pendekatan media memposisikan peran media dalam membingkai realitas sosial. Media berperan sebagai pembentuk realitas, cermin realitas, representasi realitas, dan guru-ritual-tuhan dalam aktivitas keseharian manusia. Media memainkan peran sebagai pembentuk masa depan realitas sosial (Ibrahim \& Akhmad, 2014: 3-8).

Media mengkonstruksi identitas dan ideologi di masa depan baik pada skala personal, kelompok dan institusi. Media merupakan cermin realitas sosial. Tugasnya hanyalah merefleksikan seadanya apa yang terjadi dalam kehidupan sosial Namun, dalam praktiknya asas ini tidak pernah dilakukan secara penuh. Media massa senantiasa terlibat dengan upaya merekonstruksikan realitas sosial tersebut (Hanifah, 2019: 285). Realitas sosial dalam kacamata media massa mengadung berbagai makna yang dapat diinterpretasikan tergantung kepentingan. Makna pesan ini terbangun melalui serangkaian bahasa dan simbol, baik yang bersifat verbal maupun non verbal. Konstruksi pesan dalam media massa dilakukan dengan mengikuti logika media. Dimana media diposisikan sebagai sebuah industri konten yang mampu menarik banyak audiens.

Produksi konten di media massa dilakukan sebagai upaya dalam mencerminkan realitas dan merepresentasikan pemaknaan tertentu dengan tujuan tertentu. Pesan yang ditransmisikan mengandung wacanawacana tertentu yang dikonstruksi untuk menampilkan realitas tertentu. Pada akhirnya, konstruksi realitas di media massa mengarah pada upaya membangun wacana yang didalamnya terkandung berbagai kepentingan baik secara ekonomi, politik, budaya dan agama. 
Pertarungan wacana di media massa memiliki tendensi dalam merubah persepsi dan opini masyarakat. Pertarungan wacana ini melibatkan banyak aktor yang berkepentingan (Sudibyo, 2001: 121). Keterlibatan aktor-aktor tersebut terbentuk melalui serangkaian kuasa dan simbol yang berlaku baik pada sisi personal, kelompok maupun institusi. Pertarungan wacana media massa mendefiniskan berbagai kepentingan yang dikaitkan dengan objek peristiwa, lingkungan sosial, kelompok sosial, orang lain dan diri sendiri.

Shoemaker dan Reese (1996) menyebutkan media bahwa pengaruh terhadap media massa berasal dari pekerja media, rutinitas media, organisasi media serta ideologi (Hanifah, 2019: 286-287). Media merepresentasikan pemaknaan terhadap realitas sosial. Dalam hal ini, realitas sosial dipandang sebagai sebuah konsep yang mengandung identitas, hubungan sosial dan nilai-nilai yang berlaku di masyarakat.

Media massa menjadi mediasphere. yakni sebuh ruang budaya yang melingkungi ruang publik. Mediasphere merupakan ruang publik yang termediasi. Mediasphere inilah menjadi cikal bakal perwujudan media massa sebagai public domain yang mensyaratkan adanya keterlibatan dan emansipasi dari berbagai pengguna dengan berbagai kepentingan (Hartley, 2004: 186).

Konstruksi narasi yang dilakukan dalam pengemasan pesan kontra narasi terorisme dan radikalisme pada akun @dutadamaijabar dilakukan dalam beberapa pemilihan isu. Pusat ide yang menjadi pesan media massa di akun @dutadamaijabar berkaitan dengan upayaupaya DD Jawa Barat dalam merepresentasikan nilai-nilai perdamaian, kemanusiaan, moderasi agama dan kebangsaan. Dalam ini, DD Jawa Barat menjadikan media sosialnya sebagai media pembentuk realitas dengan orientasi mewujudkan ekosistem perdamaian, sebagai cerminan realitas yang menggambarkan betapa bahayanya paham-paham terorisme dan radikalisme terhadap keutuhan bangsa dan representasi nilai toleransi dan kebangsaan.

Berdasarkan hasil observasi didapatkan bahwa core frame kontra narasi terorisme dan radikalisme pada akun @dutadamaijabar adalah gagasan yang dibangun di atas tiga narasi besar, yakni narasi kebangsaan dalam kerangka menguatkan jiwa nasionalisme anak muda di abad digital; narasi perdamaian dalam kerangka membangun keharmonisan kehidupan berlandaskan moderasi beragama; dan narasi kemanusiaan yang dibangun di atas nilai-nilai dan sikap toleransi terhadap perbedaan.

Pertama, Kontra narasi dengan core framing kebangsaan (nasionalisme). Narasi nasionalisme ini dibangun dengan mempertautkan teks, image dan foto yang mencerminkan kebangsaan. Dalam pengamatan penulis, porsi narasi ini menempati urutan kedua sebagai narasi yang mendominasi pada postingan akun @dutadamaijabar. Secara teknis, narasi yang berkaitan dengan nasionalisme atau kebangsaan menggunakan burung garuda, bendera merah-putih dan personifikasi aktor-aktor yang merupakan tokoh bangsa. Berikut contoh kontra narasi dengan isu kebangsaan.

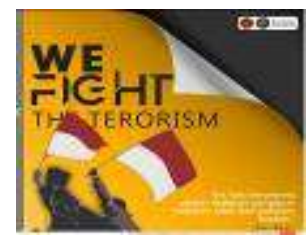

Gambar 1. Narasi kebangsaan dalam akun @dutadamaijabar

Narasi kebangsaan ini dipertautkan dengan teks yang secara tegas menunjukkan perlawanan terhadap terorisme dan radikalisme.

Kedua, kontra narasi dengan core framing narasi perdamaian. Narasi-narasi 
perdamaian dibingkai dengan konsep moderasi beragama sebagai bentuk universal dalam membangun visi kerukunan beragama. Moderasi beragama yang ada pada akun @dutadamaijabar dibangun secara simbolik berkaitan dengan moderasi Islam seagai konsep rahmatan lil alamin, fakta historis dalam doktrin agama yang berkaitan dengan perdamaian (misalnya perdamaian Hudaibiyah) dan moderasi beragama dalam bentuk peringatan harihari besar agama di Indonesia. Berikut contoh kontra narasi perdamaian.

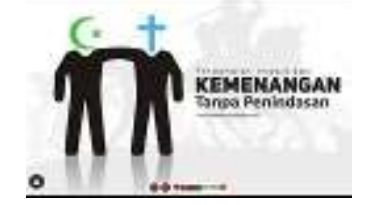

Gambar 2. Narasi perdamaian dalam akun @dutadamaijabar

Gambar di atas adalah bentuk narasi perdamaian yang berlandaskan pada moderasi Islam. simbol bulan sabit (Islam) dan Salib (Nasrani) kemudian dipertautkan dengan gambar dua bayangan yang saling merangkul adalah simbol perdamaian sebagai bentuk perlawanan terhadap terorisme dan radikalisme. Kemudian ditegaskan dengan frase Perdamaian Hudaibiyah (fakta historis); Kemenangan tanpa Penindasan yang dimaksudkan sebagai metafor untuk menyatakan bahwa perdamaian mengantarkan pada derajat kemuliaan kemanusiaan dan menghindari perpecahan.

Ketiga, kontra narasi dengan core framing narasi kemanusiaan. Narasi ini dibangun dengan penanaman mentalitas, mindset dan sikap toleran terhadap beragam perbedaan. Dalam pengamatan penulis, narasi kemanusiaan mendapat porsi paling besar yang menjadi konten pada akun @dutadamaijabar. Berikut contoh kontra narasi dengan nilai kemanusiaan.

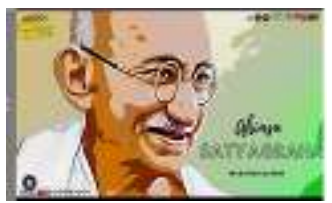

Gambar 3. Narasi kemanusiaan dalam akun @dutadamaijabar

Pada gambar di atas narasi kemanusiaan di bangun melalui sosok seorang pejuang kemanusiaan di India, Mahatma Ghandi. Konsep Ahimsa Satyagraha adalah gerakan kemanusiaan yang berdiri di atas panji-panji toleransi dan keadilan untuk melawan berbagai bentuk penindasan, ketidakadilan dan diskriminasi golongan. Selain itu, narasi kemanusiaan ini di bangun dengan mempertautkan simbolsimbol perjuangan kemanusiaan dalam menegakkan keadilan untuk semua golongan melintasi sekat-sekat formalitas agama, suku bangsa, etnis dan ras.

\section{c. Condensing Symbol dalam Proses Pembingkaian Kontra Narasi @dutadamaijabar}

Media massa baik cetak, elektronik maupun digital memiliki potensi besar sebagai kekuatan penggerak masyarakat. Media massa menjadi public domain, tempat untuk berbagai informasi, mendiskusikan kepentingan umum sekaligus membangun komunikasi setara yang berorientasi pada kesadaran (emansipatif) dan keterlibatan publik (partisipatif) (Hartley dan McKee, 2000).

Eksistensi media massa menjadi prasyarat bagi sebuah negara demokrasi. Media massa menjadi kontrol pemerintah dalam upaya membangun keharmonisan dan keterbukaan publik. Media massa memiliki peran strategis dalam konteks kebangsaan. Dalam hal ini, media massa menjadi saluran informasi sekaligus ruang komunikasi antar berbagai elemen bangsa.

Salah satu media massa yang memiliki implikasi besar dalam proses transformasi masyarakat dunia adalah internet. Sebagai sebuah teknologi digital, internet 
merupakan hasil perkembangan peradaban manusia yang bermanfaat untuk menyimpan, memanipulasi maupun menerima pesan. Media internet merupakan new media yang memungkinkan adanya konvergensi media dalam satu perangkat untuk beragam fungsi. Internet menjadi ruang komunikasi dan cara baru dalam menarasikan informasi, mengkonstruksi pesan dan citra, merefleksikan realitas dan mendorong perubahan dalam berbagai ruang kehidupan manusia (Nuruzzaman, 2018: 65).

Media internet menjadi media generasi ketiga yang memiliki karakteristik dalam upaya membangun masyarakat jaringan. Media internet membangun komunikasi melalui jaringan, bersifat virtual, interactivity dan perpaduan konten baik dalam bentuk teks, audio, image, animasi, video dan bentuk konten interaktif lainnya (Heryanto, 2018: 26-27). Karakteristik ini pada akhirnya membentuk sebuah jejaring masyarakat yang dikenal dengan istilan netizenship atau warganet. Sebuah konstruksi masyarakat siber (network society) yang berada pada ruang virtual dan memainkan peran sosial baik dalam konteks kemasyarakatan maupun berkaitan dengan aspek-aspek kebangsaan (Fahmi, 2018: 96). Dengan kata lain, media internet menjadi ruang baru dalam membangun interaksi sosial masyarakat dunia.

Salah satu media internet yang memiliki popularitas dan sering digunakan oleh masyarakat dunia adalah media sosial. Media sosial merupakan media online yang dapat menghubungkan dan merepresentasikan proses interaksi manusia. Media sosial menjadi ruang baru dalam membentuk relasi sosial di antara manusia. Terdapat berbagai platform media sosial yang banyak digunakan oleh masyarakat, antara lain facebook, Instagram, twitter, youtube, linkedin, whattapps, messenger, dan lain sebagainya. Beragam platform ini dibedakan berdasarkan konsen fitur yang menjadi keunggulannya, baik dalam bentuk fitur chating, video, foto, dan lain-lain.

Media sosial menjadi ruang praktis yang dapat menghubungkan manusia dalam berbagai aspek kehidupan. Sebagai sebuah bagian dari media massa, pengguna media sosial memiliki kewenangan secara privat dalam mengontrol akunnya untuk digunakan untuk kepentingan apapun, baik bisnis-ekonomi, pendidikan, sosial, budaya, agama maupun politik. Termasuk dalam memproduksi konten, baik konten media yang bersifat positif maupun destruktif (Baran, 2012: 415). Sebab, media (media sosial) menjadi industri konten yang mencurah diri untuk meraih audiens dan pembaca dalam jumlah besar (Hartley, 2004:187).

Salah satu media sosial yang banyak digunakan dalam keseharian masyarakat Indonesia adalah Instagram. Berdasarkan data APJII tahun 2018 tercatat bahwa pengguna Instagram di Indonesia mencapai angka 17,8 persen $(23,5$ juta) dari total pengguna media sosial sebanyak 132 juta orang. Produksi konten dalam media sosial Instagram berbasis foto dan video. Produksi wacana dalam media Instagram merupakan perpaduan antara teks, audio, image, video, animasi, foto dan bentuk lainnya. produksi konten ini dilakukan untuk mengkonstruksi berbagai realitas, wacana, isu, diskursus bahkan ideologi tertentu dengan tujuan dan motif tertentu.

Berdasarkan hasil penelitian pada akun media sosial Instagram @dutadamaijabar, peneliti menemukan bahwa analisis framing sebagai ruang pembingkaian mengenai kontra narasi terorisme dan radikalisme yang dilakukan DD Jawa Barat adalah sebagai berikut:

Tabel 2. Perangkat Framing Kontra Narasi melalui Isu Nasionalisme 


\begin{tabular}{|c|c|}
\hline Framing Devices & Reasoning Devices \\
\hline \multirow{3}{*}{$\begin{array}{l}\text { Methapors } \\
\text { Perjuanganku lebih } \\
\text { mudah karena } \\
\text { mengusir penjajah, } \\
\text { perjuanganmu akan } \\
\text { lebih sulit karena } \\
\text { melawan bangsamu } \\
\text { sendiri }\end{array}$} & \multirow{7}{*}{ 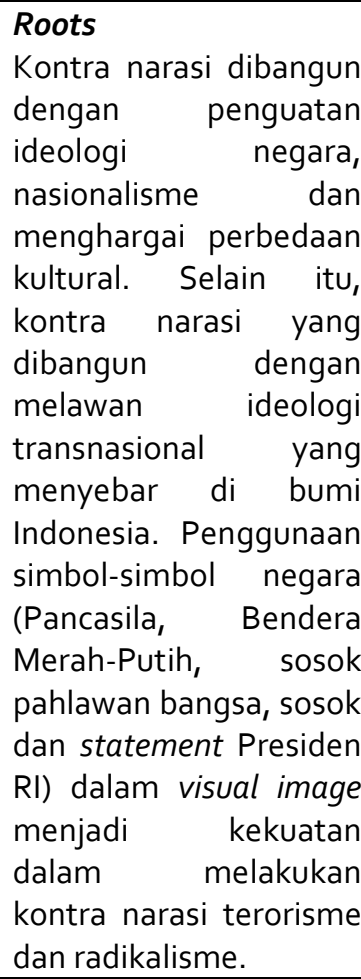 } \\
\hline & \\
\hline & \\
\hline \multirow{4}{*}{$\begin{array}{l}\text { Darahmu tumpah di } \\
\text { tanah pusaka, } \\
\text { jiwamu mengawal } \\
\text { tegaknya Indonesia, } \\
\text { engkau pahlawanku, } \\
\text { engkau kususma } \\
\text { negaraku. }\end{array}$} & \\
\hline & \\
\hline & \\
\hline & \\
\hline Exemplars & Appeals to principle \\
\hline Infiltrasi Ideologi & Terorisme musuh \\
\hline Mewaspadai & bersama dan tindakan \\
\hline Transnasional, & biadab yang harus \\
\hline Membendung & dilawan oleh seluruh \\
\hline $\begin{array}{l}\text { ancaman Politisasi } \\
\text { agama. }\end{array}$ & $\begin{array}{lr}\text { elemen } & \text { bangsa. } \\
\text { Indonesia } & \text { negara }\end{array}$ \\
\hline & majemuk, menghargai \\
\hline $\begin{array}{l}\text { Mengkomunikasikan } \\
\text { perbedaan, } \\
\text { menguatkan } \\
\text { perdamaian. }\end{array}$ & $\begin{array}{l}\text { perbedaan } \\
\text { menguatkan } \\
\text { perdamaian. }\end{array}$ \\
\hline
\end{tabular}

\section{Catchprases}

We figt Teorisisme!

Tidak Ada Ruang

bagi teroris di bumi

pertiwi

\begin{tabular}{lr}
\hline Depiction & \\
Tindakan & teorisme \\
adalah raksi \\
pengecut, tindakan \\
tidak bermartabat \\
dan biadab \\
\hline
\end{tabular}

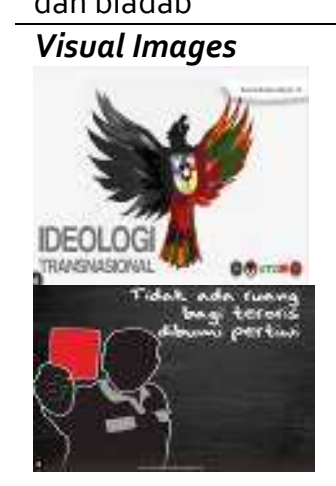

Sumber: Observasi penulis pada akun @dutadamaijabar, 2020.

Tabel 2 di atas menunjukkan bagaimana akun @dutadamaijabar mengemas pesan dalam rangka kontra narasi terorisme dan radikalisme di media sosial melalui berbagai alternatif pemilihan isu. Isu-isu sentral yang dipilih berkaitan dengan dimensi kebangsaan, moderasi beragama, toleransi, perdamaian dan kemanusiaan. Tabel 2 menunjukkan bagaimana isu nasionalisme mendapat porsi yang dominan kedua dalam melakukan kontra narasi terorisme dan radikalisme di dunia maya.

Selain itu, sisi menarik pada framing pesan kontra narasi melalui isu nasionalisme adalah adanya penggunaan visual image sebagai simbol negara, seperti burung garuda, bendera merah-putih, foto pahlawan, foto presiden RI dan quotes atau pernyataan klaim moral dari presiden. Pembingkaian pesan dengan mengambil image yang memiliki keterkaitan erat dengan dimensi kenegaraan menunjukkan adanya pertautan yang tidak bisa dipisahkan antara negara dan upayanya dalam melawan terorisme dan radikalisme. Sebab, terorisme adalah musuh negara yang dipandang mengancam keutuhan dan persatuan negara.

Media sosial sebagai ruang komunikasi virtual berperan dalam proses penampilan dan representasi kepentingan, tujuan, maksud dan ideologi tertentu. Dalam hal ini, publikasi konten @dutadamaijabar dari sudut pandang framing kontra narasi terorisme dan radikalisme menunjukkan adanya upaya membangun representasi diri di dunia maya.

Representasi adalah "pelukisan kembali realitas" yang tidak dapat "dihadirkan" (to present), sehingga diperlukan "model penghadiran kembali realitas" (to represent) lewat berbagai model bahasanya (verbal, visual, gambar, citra). Relasi yang terbangun adalah relasi relatif-simetris, 
seperti refleksi cermin (mirror image), berdasarkan prinsip kesamaan, keserupaan dan ikonisitas (iconicity) (Piliang, 2012: 149). Penggunaan simbol burung garuda, bendera Indonesia, foto pahlawan dan foto presiden merepresentasikan makna dan nilai kebangsaan dalam melawan terorisme di Indonesia.

Tabel 3. Perangkat Framing Kontra Narasi melalui Isu Moderasi Islam dan Perdamaian

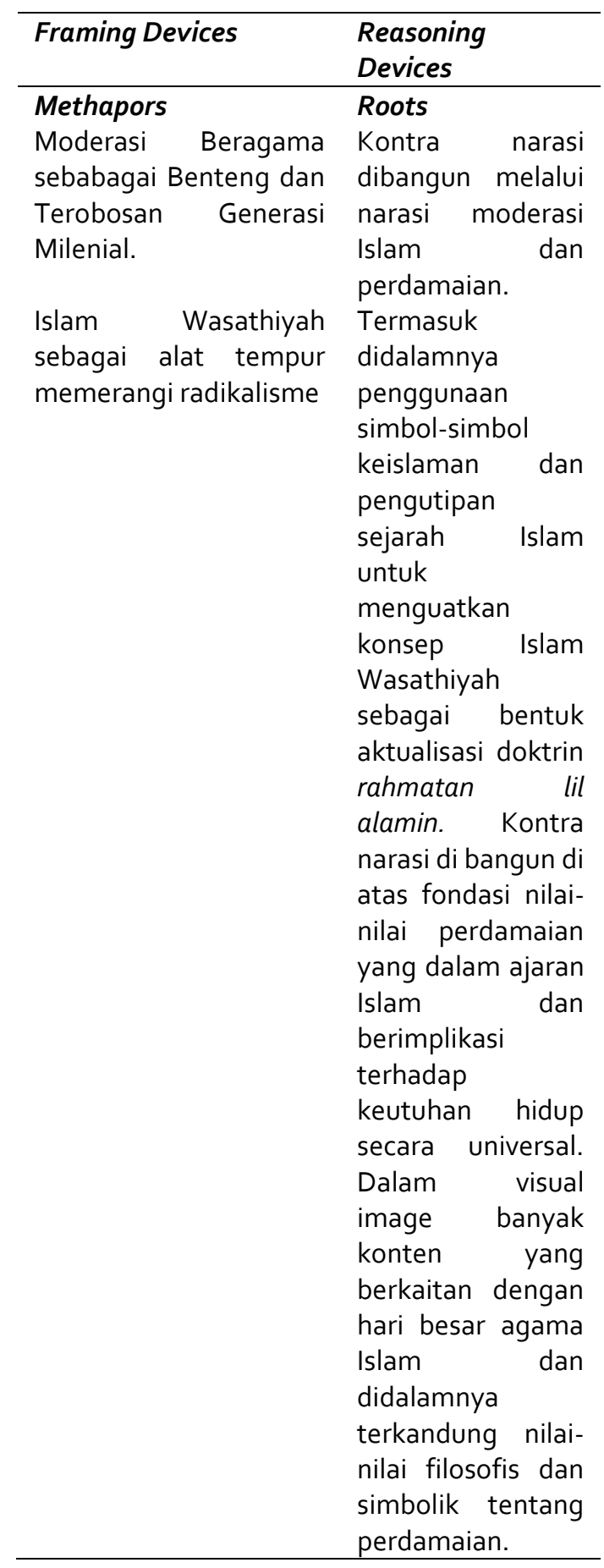

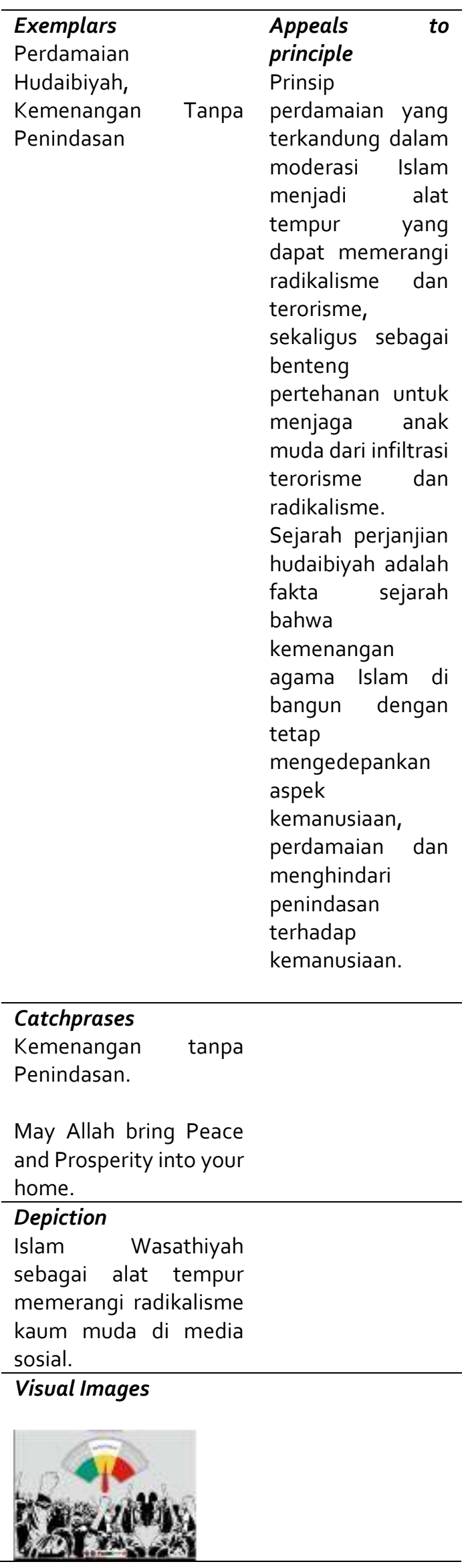




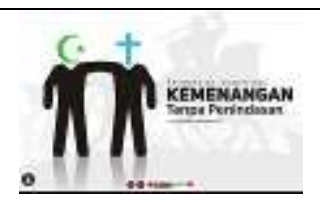

Sumber: Observasi penulis pada akun @dutadamaijabar, 2020.

Tabel 3 adalah perangkat framing akun @dutadamaijabar dalam melakukan kontra narasi terorisme dan radikalisme yang di bangun di atas nilai-nilai moderasi Islam dan perdamaian. Isu mengenai moderasi Islam dijadikan sebagai kontra isu radikalisme dan terorisme. Hal ini dipandang sebagai sebuah upaya dalam menjawab sorotan global mengenai Islamophobia dan Islam sebagai agama kekerasan.

Kontra narasi dengan mengambil isu moderasi Islam dan perdamaian dirumuskan melalui perpaduan teks, image, foto dan simbol-simbol tertentu. Terutama konstruksi narasi yang bertujuan untuk memberikan pembingkaian bahwa Islam adalah agama perdamaian yang mencintai perbedaan dan membenci perpecahan. Oleh karenanya, @dutadamaijabar ingin menegaskan bahwa moderasi beragama (Islam) sebagai benteng yang mampu menguatkan generasi muda dalam melawan terorisme dan radikalisme di media sosial.

Hal lainnya yang menjadi kekuatan dalam narasi ini adalah pemilihan narasi historis berkaitan dengan kuatnya perdamaian dalam agama Islam. Hal ini dapat dilihat dari konstruksi narasi yang mengambil sudut historis tentang perdamaian hudaibiyah yang melibatkan masyarakat beragam tetapi menguatkan kemenangan Islam, kemenangan kemanusiaan tanpa adanya penindasan dalam proses mencapai kemenangan Islam tersebut.

Konsep nilai perdamaian dan moderasi Islam dalam kontra narasi terorisme dan radikalisme ini dapat dibangun di atas kesadaran diri, proses penerimaan terhadap diri, menjauhi prasangka, merayakan keberagaman sebagai sebuah anugerah, konflik tanpa kekerasan dan perpecahan, berdamai dengan semesta dan berdamai dengan takdir Allah Swt (Wahab, 2020: 134140). Kontra narasi ini sekaligus digunakan untuk melawan segala bentuk terorisme dan radikalisme yang mengatasnamakan agama. Sehingga opini yang mendiskreditkan salah satu agama sebagai agama kekerasan dan perpecahan adalah tujuan dari kontra narasi ini.

Dalam hal ini, media massa seperti internet dan media sosial memiliki peran signifikan dalam merepresentasikan produksi konten yang positif untuk penguatan nilai-nilai perdamaian. Media massa, apapun bentuknya, dapat menjadi saluran yang memberikan efek terhadap manusia, baik secara kognitif, afektif dan behavioural. Oleh sebab itu, kontra narasi yang dilakukan dengan pemilihan isu moderasi agama dan perdamaian akan memberikan stimulus kepada masyarakat bahwa terorisme tidak ada kaitannya sama sekali dengan ajaran agama. Terorisme adalah kejahatan kemanusiaan yang seringkali berkecambah dalam momentum politik (Fahmi, 2018: 101).

Tabel 4. Perangkat Framing Kontra Narasi melalui Isu Toleransi dan Kemanusiaan

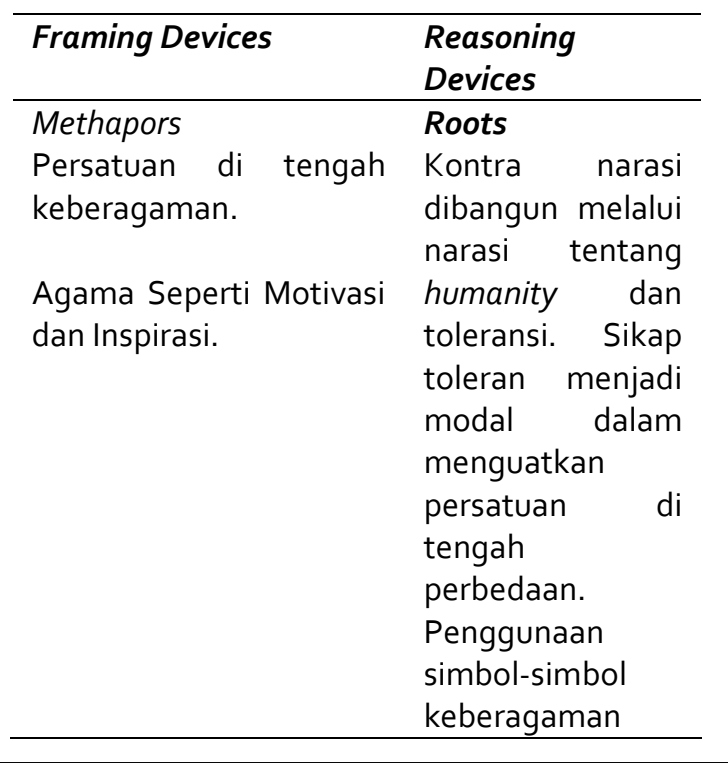




\begin{tabular}{|c|c|}
\hline & $\begin{array}{l}\text { dalam visual } \\
\text { image } \\
\text { menunjukkan } \\
\text { bagaimana } \\
\text { pentingnya } \\
\text { menguatkan nilai } \\
\text { toleransi demi } \\
\text { kemanusiaan. } \\
\text { Baik toleransi } \\
\text { karena adanya } \\
\text { perbedaan } \\
\text { agama, suku } \\
\text { bangsa, etnis, } \\
\text { golongan dan lain } \\
\text { sebagaianya. } \\
\text { Kontra narasi ini } \\
\text { untuk lingkup } \\
\text { menguatkan } \\
\text { dimensi } \\
\text { kemanusiaan } \\
\text { dalam kebangsaan. }\end{array}$ \\
\hline $\begin{array}{l}\text { Exemplars } \\
\text { Dengan senapan kamu } \\
\text { bisa membunuh } \\
\text { terorisme. Dengan } \\
\text { edukasi kamu bisa } \\
\text { membunuh terorisme, } \\
\text { dan dengan pena kamu } \\
\text { bisa membunuh } \\
\text { terorisme. }\end{array}$ & $\begin{array}{l}\text { Appeals to } \\
\text { principle } \\
\text { Prinsip ahimsa } \\
\text { satyagraha } \\
\text { menjadi pijakan } \\
\text { dalam } \\
\text { menguatkan } \\
\text { kemanusiaan. } \\
\text { Selain itu, klaim } \\
\text { moralitas tentang } \\
\text { pentingnya } \\
\text { toleransi dan } \\
\text { kemanusiaan } \\
\text { dalam melawan } \\
\text { terorisme dan } \\
\text { radikalisme } \\
\text { dikuatkan dengan } \\
\text { adanya } \\
\text { pandangan } \\
\text { bahwa toleransi } \\
\text { adalah nilai yang } \\
\text { harus diwariskan. } \\
\text { Serta melawan } \\
\text { terorisme secara } \\
\text { mutlak dengan } \\
\text { senjata, edukasi } \\
\text { dan pena atau } \\
\text { tulisan. Agama } \\
\text { sebagai pijakan } \\
\text { dalam } \\
\text { menguatkan } \\
\text { sikap toleran dan } \\
\text { empati } \\
\text { kemanusiaan } \\
\text { melarang adanya }\end{array}$ \\
\hline
\end{tabular}

perpecahan, bukan perbedaan.

\section{Catchprases \\ Manusia harus belajar membenci agar bisa memahami apa arti mencintai.}

Ahimsa Satyagraha

Depiction
Agama melarang
adanya perpecahan
bukan perbedaan.
Tugas maha besar
generasi kita adalah
mewariskan toleransi
bukan kekerasan.

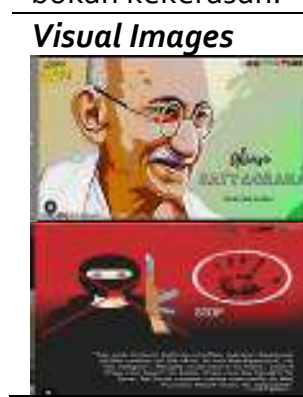

Sumber: Observasi penulis pada akun @dutadamaijabar, 2020.

Tabel 4 adalah kontra narasi terorisme dan radikalisme yang dikemas oleh @dutadamaijabar melalui isu toleransi dan kemanusiaan. Isu ini mendapat porsi terbesar yang mendominasi narasi-narasi dalam melawan terorisme dan radikalisme di dunia maya oleh DD Jawa Barat. Hal ini menjadi wajar, sebab isu toleransi dan kemanusiaan adalah modal kuat yang harus dipropagandakan kepada setiap generasi muda sebagai benteng dalam menjaga keutuhan negara.

Toleransi adalah sikap menerima berbagai perbedaan dan menjaga diri dan kelompok sosial dari segala bentuk perpecahan. Narasi tentang toleransi dan 
kemanusiaan memiliki pertautan yang erat pada akun @dutadamaijabar. Narasi ini dibangun dengan menguatkan simbolsimbol keberagaman sebagai sebuah modal sosial dalam menegaskan jati diri bangsa dan merekatkan persatuan dan kesatuan.

Simbol-simbol keutuhan itu terkandung baik dalam teks, image dan ikon-ikon yang dipandangmerepresentasikan nilai-nilai persamaan, sikap toleran dan kemanusiaan. Kerangka produksi pesan yang berkaitan dengan isu toleransi dan kemanusiaan ini selain dibangun melalui narasi-narasi perbedaan, juga berkaitan dengan momentum atau peristiwa kemanusiaan yang aktual terjadi. Misalnya, bagaimana @dutadamaijabar membuat konten untuk menghimbau dan mengajak audiens agar berpartisipasi aktif dalam upaya meringankan beban korban bencana sosial, bencana alam dan bencana kemanusiaan.

Konstruksi narasi toleransi dibangun melalui proses pendefinisian dan menampilkan citra toleransi melalui simbolsimbol tertentu. Secara konsepsional, toleransi berkaitan erat dengan dimensi keberagamaan seseorang. Dalam hal ini, diperhatikan dalam beragama bukan to have religion, akan tetapi being religious. Dalam to have religion yang dipentingkan adalah formalisme agama sebagai kata benda. Sedang dalam being religius yang dipentingkan adalah penghayatan dan aktualisasi terhadap substansi nilai-nilai luhur agama (Dewi \& Triandika, 2020: 28).

Oleh karenanya, nilai toleransi menjadi narasi yang harus dibangun di ruang-ruang virtual untuk menguatkan kemanusiaan. Nilai toleransi adalah wujud dari persamaan sebagai manusia dan upaya untuk saling memuliakan sebagai sesame manusia. Toleransi dalam konteks sosial budaya dan agama yang berarti sikap dan perbuatan yang melarang adanya diskriminasi terhadap kelompok-kelompok yang berbeda atau tidak dapat diterima oleh mayoritas dalam suatu masyarakat (Digdoyo, 2018: 48). Toleransi adalah nilai universal yang harus dimiliki oleh siapapun. Toleransi adalah wujud kemanusiaan dalam menghargai setiap perbedaan, merawat keharmonisan dan menghindari segala bentuk perpecahan dan kekerasan yang berorientasi pada penindasan.

Media sosial sebagai bagian dari media massa memiliki peran signifikan dalam menyampaikan pesan-pesan toleransi, perdamaian dan kemanusiaan kepada seluruh pihak. sehingga, dalam kacamata ini, media massa apapun bentuknya memiliki tanggung jawab sosial dalam memberikan perlindungan dan harus memastikan dalam proses produksi kontenkonten media yang menguatkan sikap toleransi dan kemanusiaan di antara berabagi pihak.

Dengan begitu, media massa menjadi simpul-simpul jaringan yang dapat menguatkan relasi sosial di antara manusia. Pada titik inilah, media massa (internet) memiliki tanggung jawab dalam proses perubahan sosial dan menguatkan dimensi keagamaan. Sehingga propaganda agama menjadi nilai substansial dan sacral yang terus dijaga dan diimplementasikan dalam keseharian manusia (Rustandi, 2019: 88).

\section{Kesimpulan}

Merujuk pada konsep framing (media package) yang digagas oleh William A. Gamson dan Modigliani. Maka pembingkaian konten media yang dilakukan oleh DD Jawa Barat melalui akun Instagram @dutadamaijabar dalam melakukan kontra narasi terorisme dan radikalisme terdiri dari dua struktur utama yakni, core frame sebagai pusat ide dalam produksi wacana dan narasi dalam bentuk konten media massa dan condensing symbol sebagai perangkat pembingkaian secara teknis yang mempertautkan antara teks, 
video, audio, image dan bentuk-bentuk lainnya.

Pada struktur yang pertama, core framing yang menjadi isu strategis dalam melakukan counter aksi dan narasi terorisme dan radikalisme di media sosial terdiri dari tiga isu utama. Yakni, narasi kebangsaan yang berorientasi pada perwujudan nasionalisme unggul di abad digital; narasi perdamaian yang berlandaskan pada moderasi beragama dalam membentuk ekosistem perdamaian; dan narasi kemanusiaan untuk menguatkan sikap toleransi di antara sesama bangsa demi terciptanya keutuhan negara.

Pada struktur yang kedua, condensing symbol dilakukan dengan mempertautkan teks, video, audio, image dan bentuk lainnya untuk menunjukkan pembingkaian konten-konten media sebagai bentuk perlawanan terhadap terorisme dan radikalisme dalam ruang-ruang virtual. Perangkat simbolik dalam upaya pembingkaian konten media ini dilakukan dengan mengikuti kerangka framing devices dan reasoning devices.

Duta Damai Dunia Maya (DD) Regional Jawa Barat secara konsisten melakukan kontra narasi terorisme dan radikalisme di dunia maya. Target dan sasaran gerakan ini adalah sebagai upaya preventif dan edukatif untuk menguatkan generasi muda sebagai promotor perdamaian. Pada praktiknya, orientasi kontra narasi terorisme dan radikalisme yang dilakukan oleh DD Jawa Barat meliputi dua bentuk gerakan yakni kontra narasi secara online yang dilakukan dengan memproduksi konten-konten positif baik di website maupun di jejaring media sosial. Kontra narasi secara ofline yang dilakukan dalam bentuk dialog, workshop, pelatihan jurnalistik, kampanye damai dan deklarasi damai dengan berkolaborasi bersama komunitas lainnya.

Dalam proses produksi konten kreatif, DD Jawa Barat melakukan beberapa tahapan dari mulai riset kebutuhan dan trend aktual, proses produksi bersama antara bloger, DKV dan IT, sampai dengan monitoring respon konten. Komposisi tim dalam proses kontra narasi terorisme dan radikalisme yang dilakukan oleh DD Jawa Barat terdiri dari tim bloger, tim DKV dan tim IT, sesuai dengan pembidangan keterampilan dalam pembuatan konten. Proses ini dilakukan dalam memproduksi konten untuk website maupun media sosial. Termasuk didalamnya konten kreatif kontra narasi terorisme dan radikalisme pada akun @dutadamaijabar.

\section{Referensi}

Achmad, N. (2001). Pluralitas Agama, Kerukunan dalam Keragaman. Jakarta: Kompas.

Ahdar. (2017). Tinjauan Kritis dan Menyeluruh terhadap Fundamentalisme dan Radikalisme Islam Masa Kini, KURIOSITAS, 11(1), 19-36.

Asosiasi Penyelenggara Jasa Internet Indonesia (APJII), 2020. Laporan Survei Penetrasi dan Perilaku Pengguna Internet di Indonesia Tahun 2018. https://apjii.or.id diakses pada tanggal 26 Agustus 2020.

Asrori, A. (2015). RADIKALISME DI INDONESIA: Antara Historisitas dan Antropisitas, Kalam: Jurnal Studi Agama dan Pemikiran Islam, 9(2), 253-268.

Badan Pusat Statistik (BPS) Provinsi Jawa Barat, 2020. Jabar dalam Angka Tahun 2020. https://jabar.bps.go.id diakses pada 26 Agustus 2020.

Baran, S. J. (2012). Pengantar Komunikasi Massa: Melek Media dan Budaya. Jakarta: Erlangga.

Dewi, D. K., \& Triandika, L. S. (2020). Konstruksi Toleransi pada Akun 
Media Sosial Jaringan Gusdurian, Lentera, 4(1), 19-39.

Digdoyo, E. (2018). Kajian Isu Toleransi Beragama, Budaya, dan Tanggung Jawab Sosial Media, JPK (Jurnal Pancasila dan KewarganegaraaN), 3(1), 42-60.

Eriyanto. (2002). Analisis Framing: Konstruksi, Ideologi Dan Politik Media. Yogyakarta: LKiS.

Fahmi, N. (2018). Melawan Aksi Terorisme di Media Sosial: Penggunaan Tagar \#KAMITIDAKTAKUT di Twitter, KOMUNIKA, 1(1), 87-106.

Fakhruroji, M. (2015). Mediatization of religion in "texting culture": selfhelp religion and the shifting of religious authority, Indonesian Journal of Islam and Muslim Societies, 5(2), 231-254.

Fakhruroji, M. (2018). Digitalizing Islamic lectures: Islamic apps and religiousengagement in contemporary Indonesia, Contemporary Islam, 13 (2), 201-215.

Hanifah, U. (2019). Analisis Framing Tentang Wacana Terorisme di Media Massa (Majalah Sabili), KOMUNIKA: Jurnal Dakwah dan Komunikasi, 13(22), 283-298.

Hartley, J. (2004). Communication, Cultural, and Media Studies: The Key Concepts (Terj. Penerbit Jalasutra). London: Routledge.

Hartley, J., \& McKee, A. (2000). The Indigenous Public Sphere: The Reporting and Reception of Aboriginal Issues in the Australian Media. Oxford: Oxford University Press.

Heryanto, G. G. (2018). Media Komunikasi Politik: Relasi Kuasa Media di Panggung Politik. Yogyakarta: IRCiSoD.

Ibrahim, I. S., \& Akhmad, B. A. (2014). Komunikasi \& Komodifikasi:
Mengkaji Media dan Budaya dalam Dinamika Globalisasi. Jakarta: Yayasan Pustaka Obor Indonesia.

Markum., \& Winarno. (2020) Upaya Membangun Karakter Bangsa Mencegah Radikalisme Terorisme di Indonesia, Jurnal PPKn, 8(1), 3759.

McLuhan, M. (1964). Understanding Media: The Extension of Man. London: Routledge.

Muthohirin, N. (2015). Radikalisme Islam dan Pergerakannya di Media Sosial, Jurnal Ilmu-llmu Keislaman Afkaruna, 11(2), 240-259.

Nasrullah, R. (2015). Media Sosial: Perspektif Komunikasi, Budaya, dan Sosioteknologi. Bandung: Simbiosa Rekatama Media.

Nurdiarti, R. P. (2018). Media Sosial, Pola Interaksi dan Relasi Sosial pada Grup Whatsapp Alumni SDK. St. Maria Blitar, ETTISAL Journal of Communication, 3(1), 49-61.

Nuruzzaman, M. (2018). Terorisme dan Media Sosial Sisi Gelap Berkembangnya Teknologi Informasi Komunikasi, Syntax Literate: Jurnal Ilmiah Indonesia, 3(9), 61-76.

Peraturan Badan Nasional Penanggulangan Terorisme Nomor 4 Tahun 2019 tentang Duta Damai sebagai Relawan Penggerak Perdamaian dalam Pencegahan Radikal Terorisme di Dunia Maya.

Piliang, Y. A. (2012). MASYARAKAT INFORMASI DAN DIGITAL: Teknologi Informasi dan Perubahan Sosial, Jurnal Sosioteknologi, 11(27), 143-155.

PPIM UIN Syarif Hidayatullah Jakarta \& Convey Indonesia. (2018). API DALAM SEKAM: Keberagamaan Muslim Gen-Z. Survei Nasional 
tentang Keberagamaan di Sekolah dan Universitas di Indonesia.

Rustandi, R. (2019). Cyberdakwah: Internet sebagai Media Baru dalam Sistem Komunikasi Dakwah Islam, Nalar: Jurnal Peradaban dan Pemikiran Islam, 3(2), 84-95.

Shoemaker, P. J., \& Reese, S.D. (1996). Mediating The Message: Theories of Influences on Mass Media Content. Toronto: Longman Publishers USA.

Sobur, A. (2001). Analisis Teks Media: Suatu Pengantar Untuk Analisis Wacana, Analisis Semiotik Dan Analisis Framing. Bandung: PT. Remaja Rosda Karya.

Sudibyo, A. (2001). Politik Media dan Pertarungan Wacana. Yogyakarta: LKiS.

Sutantohadi, A., \& Wakhidah, R. (2017). Bahaya Berita Hoax dan Ujaran Kebencian pada Media Sosial terhadap Toleransi Bermasyarakat, JURNAL PENGABDIAN KEPADA MASYARAKAT, 1(1), 1-5.

Turmudi, E. (2012). Melihat Kembali Radikalisme Islam di Indonesia dan Upaya-Upaya Pencegahannya, Jurnal Masyarakat dan Budaya, 14(2).

Turmudi, E (ed). (2005). Islam dan Radikalisme di Indonesia. Jakarta: LIPI Press.
Utomo, G. (2016). Merancang Strategi Komunikasi Melawan Radikalisme Agama, Jurnal Komunikasi Islam, 6(1), 93-128.

UU No. 52018 Tentang Perubahan Atas Undang-Undang Nomor 152003 Tentang Penetapan Peraturan Pemerintah Pengganti UndangUndang Nomor 1 Tahun 2002 Tentang Pemberantasan Tindak Pidana Terorisme Menjadi UndangUndang.

Wahab, M. R. N. F. (2020. Kontribusi Young Interfaith Peacemaker Community (YIPC) Dalam Menyebarkan Narasi Kontra Radikalisme, Al-Mada: Jurnal Agama Sosisal dan Budaya, 3(2), 128-150.

We Are Social, 2020. Digital 2020, Global Overview Report. https://wearesocial.com diakses pada 26 Agustus 2020. 